\title{
PERSPEKTIF KIAI: KETIKA PESANTREN DAN PENDIDIKAN KEAGAMAAN DIUNDANGKAN
}

\author{
Oleh: \\ Maskuri \& Minhaji \\ Universitas Ibrahimy Situbondo \\ masykuri.ismail@gmail.com \\ moh_minhaji@yahoo.co.id
}

\begin{abstract}
:
The contribution of pesantren to the continuity of national life and statehood cannot be calculated with a numerical value. The sacrifice of the kyai as the central leader in the pesantren has also been proven in the history of the nation. During the colonial period carried out by the Dutch colonies and allies, in a period of more than 300 years, the kyai and pesantren appeared with zeal, with the motto of lovng the homeland is part of faith. The struggle of kyai did not stop after independence, so kyai and all pesantren committed to maintaining and filling independence in accordance to the purpose of the founder of the nation. So then it is time for the State to attend to the continuity of the pesantren through the policy of forming law. However, regulations through this law should not be used as a tool for the State to intervene in pesantren. Let the pesantren with their peculiarities continue to carry out all forms of service to the community. This paper is intended to see the views of kyai on Rancangan Undang-Undang (Draft of Law) on Islamic Boarding Schools and Islamic Education. This paper also analyzes using a public policy perspective on the content of draft of law for the Islamic Boarding School and Religious Education.
\end{abstract}

Keyword: Pesantren, Kiai, Pembentukan Undang-Undang, dan Kebijakan Publik

\section{A. Pendahuluan}

Sungguh sangat menggembirakan dengan munculnya berbagai macam varian pondok pesantren yang ada di Indonesia. Dari sekian varian bentuk pondok pesantren, secara garus besar dibagi dalam tiga bentuk, yaitu a) pondok pesantren salafiyah, b) pondok pesantren khalafiyah, dan c) pondok pesantren campuran atau kombinasi. ${ }^{1}$ Secara epistemologi,

1 Profil Pondok Pesantren Mu'adalah (Jakarta: Direktorat Jenderal Kelembagaan Agama Islam/Direktorat Pendidikan Keagamaan dan Pondok Pesantren Departemen 
bentuk pondok pesantren tersebut tidak bisa dipisahkan dari lima unsur wajib yang harus dipenuhi agar memenuhi sebagai bentuk pondok pesantren. Lima unsur itu adalah 1) Kiai, 2) santri, 3) pengajian kitab kuning, 4) asrama tempat menginap, dan 5) masjid sebagai pusat kegiatan ibadah dan pelayanan masyarakat. ${ }^{2}$ Penelitian Dhofier yang mewajibkan syarat rukun pesantren tersebut dipertegas dalam pasal 5 Peraturan Menteri Agama Nomor 13 Tahun 2014 tentang Pendidikan Keagamaan Islam. Permenag tersebut mendefinisikan pondok pesantren sebagai lembaga pendidikan keagamaan Islam yang diselenggarakan oleh masyarakat yang menyelenggarakan satuan pendidikan pesantren dan/ a tau secara terpadu menyelenggarakan jenis pendidikan lainnya.

Berbagai pihak sudah "sepakat" bahwa pondok pesantren identik dengan lembaga pendidikan (Islam) tradisional. Lembaga pendidikan yang tetap mempertahankan tradisi keilmuan, hubungan kiai dan santri, bahkan pondok pesantren dikatakan sebagai sub kultur. Dalam pandangan Mastuhu, pondok pesantren disebutnya sebagai lembaga pendidikan tradisional karena menjalankan aktifitasnya dalam pembelajaran, memahami, mendalami, menghayati, dan mengamalkan ajaran Islam yang menekankan aspek moral keagamaan sebagai basis pengamalan kehidupan sehari-hari. ${ }^{3}$ Pembelajaran yang dimaksudkan adalah mengajarkan kitab-kitab kuning berbasis tulisan ulama-ulama salafus sholeh.

Ada yang menggelitik benak cendekiawan muslim ketika berkunjung ke beberapa Negara yang memiliki paham sekuler. Nasarudin Umar, ketika menjadi nara sumber dalam salah satu forum di Amerika Serikat mendapat pertanyaan yang membuat hatinya tergelitik. Bagi masyarakat Amerika, pondok pesantren itu tempat melakukan kaderisasi para teroris. Mereka membayangkan dan berasumsi bahwa pesantren telah berhasil mendidik para radikalis dan melakukan tindak kekerasan yang melanggar terhadap hak asasi mansuia. Pandangan mereka karena melihat sosok Abu Bakar Ba'asyir, pengasuh dan pemimpin pondok pesantren Ngruki. Sosok bombarder Amrozi menjadi salah satu orang yang sukses dikader dan dididik di pesantren Ngruki. ${ }^{4}$ Kesimpulan mereka

Agama, 2004), 15.

2 Zamahsyari Dhofier, Tradisi Pesantren: Studi tentang Pandangan Hidup Kiai (Jakarta: LP3ES, 1982), 43-55.

${ }^{3}$ Mastuhu, Dinamika Sistem Pendidikan Pesantren ( Jakarta: INIS, 1994), 55

4 Nasaruddin Umar, Rethinking Pesantren (Jakarta: PT. Elex Media Komputindo, Kompas Gramedia, 2014), v. 
terhadap keberadaan pesantren di Indonesia tidak ada ubahnya dengan pesantren di Afganistan yang melahirkan pasukan Taliban. Betapa hebatnya peran media dan teknologi informasi dalam membentuk opini publik (dunia) dalam melihat pesantren.

Penulis juga pernah merasakan hal yang menggelitik, saat menjadi nara sumber di Surabaya, ada orang yang masih beranggapan bahwa pesantren itu lembaga pendidikan yang hanya mengajarkan kitab gundul tanpa mempelajari ilmu pengetahuan lainnya. Ketika penulis bertanya balik, dari mana anda memiliki pandangan tersebut? Jawabannya sederhana, bahwa ketika diberi tugas melakukan survei dan monitoring program pemberdayaan pesantren kebetulan melihat keberadaan pesantren yang kurang memperhatikan aspek kesehatan dan kebersihan, yang dipelajari santri hanya ilmu-ilmu yang ada dalam kitab gundul. Ketika penulis menjelaskan bahwa pesantren tempat memperdalam ilmu keagamaan Islam bukan hanya mengajarkan kajian kitab kuning. Memang mengaji kitab kuning menjadi makanan pokok dalam proses pembelajaran. Jadi, asumsi masyarakat dan persepsi publik terhadap keberadaan pesantren sangat variatif, tergantung sumber dan informasi yang diterima.

Keberadaan pesantren tidak hanya dipandang dari persperktif variasi, metodologi pembelajaran, tipologi, dan penyelenggaraan pendidikan berbasis kultur. Menurut 0 Neill, sebagaimana tulis Ahmad Arifi, pendidikan pesantren dibagi ke dalam tiga tipe ideology. Pertama, ideologi konservatif atau tradisional. Tipe ini identic dengan tipe pesantren salafiyah. Hubungan guru (kiai) dan murid (santri) berlangsung dalam proses "ketundukan total". Santri tidak boleh bertentangan dan melawan apa yang menjadi garis pemikiran dan ideology yang dibangun oleh kiai. Santri wajib menuntut ilmu melalui transfer of knowledge (transfer atau pemindahan ilmu dari seorang kiai/guru kepada murid/santri) yang dilakukan oleh otoritas kiai. Kedua, ideologi modern, yakni proses pendidikan yang memberikan kebebasan kepada murid/santri dalam proses pencarian ilmu. Dalam kontek lain, ideologi ini juga disebut sebagai ideologi pendidikan liberal. Santri menentukan cara, metode, dan bakat keilmuan secara bebas sesuai dengan bakat yang dimiliki. Pesantren sebagai tempat penyelenggaraan pendidikan berperan sebagai fasilitator bagi peserta didik/santri. Tidak ada pemaksaan kehendak yang dilakukan oleh kiai/murid, bahkan santri sangat terbuka untuk melakukan kritik terhadap pemikiran kiai jika dirasa 'memiliki kesalahan'. Namun demikian, kebebasan yang diberikan kepada santri dalam proses pembelajaran tidak serta merta bebas tanpa batas. Ketiga, 
ideologi pendidikan transformative atau partisipatoris. Dalam kontek ideologi tipe ini, pesantren bukan hanya memerankan diri sebagai penyelenggaraan pendidikan yang berorientasi santri agar membekali diri dalam proses keilmuan. Ada peran penting lainnya yang harus dilakukan oleh pesantren, yaitu pemberdayaan masyarakat. Kepedulian pesantren terhadap masyarakat pesantren yang ada di sekitarnya menjadi penting untuk bersama-sama meningkatkan taraf hidup secara layak. Arifi memberi contoh pesantren Maslakul Huda, Pati yang dipimpin oleh KH. M.A. Sahal Mahfud. Bagi Kiai Sahal, pemberdayaan pesantren merupakan keharusan pesantren agar ikut memikirkan keberdayaan hidup mandiri dan sejahtera. ${ }^{5}$

Dalam pandangan penulis, ideologi pendidikan transformatif juga dilakukan oleh Kiai Syamsul Arifin dan Kiai As'ad Syamsul Arifin dalam mengelola dan menyelenggarakan Pesantren Salafiyah Syafi'iyah. Beliau berdua, pendiri dan pengasuh pesantren tidak hanya memikirkan pendalaman dan pengamalan ilmu para santri. Pesantren Sukorejo hadir di tengah-tengah masyarakat untuk ikut terlibat dalam proses pemberdayaan. Tanah yang diperoleh KHR. Syamsul Arifin melalui proses yang cukup panjang pada kahirnya "diberikan" kepada masyarakat dengan harga yang sangta murah. Langkah Kiai Syamsul tersebut dilakukan dalam rangka mengajak masyarakat untuk bersama-sama membangun pesantren sebagai tempat memberdayakan diri. Kebijakan dan kebijaksanaan pendiri dan pengasuh Pesantren Sukorejo terus berlangsung hingga sekarang. Dalam hal peningkatan taraf hidup masyarakat, Pesantren Sukorejo tidak melakukan monopoli ekonomi. Untuk itu, Kiai As'ad memberi kesempatan kepada masyarakat untuk ikut melayani kebutuhan makan para santri, sehingga ada efek ekonomi bagi masyarakat.

Sejalan dengan dinamika perkembangan teknologi dan informasi, ternyata sistem pembelajaran pondok pesantren telah diadopsi oleh berbagai institusi lain, termasuk Negara. Kebijakan full day school yang dilakukan Kementerian Pendidikan dan Kebudayaan Republik Indonesia, ${ }^{6}$ dengan menerapkan proses pembelajaran selama 5 hari, dan dimulai dari pukul 07.00 - 16.30 wib. Diakui atau tidak, kebijakan ini merupakan bentuk lain dari sistem pondok pesantren. Memang tidak sepenuhnya, tetapi suasana itu menggambarkan bagaimana pondok pesantren menjadi

5 Ahmad Arifi, Politik Pendidikan Islam: Menelusuri Ideologi dan Aktualisasi Pendidikan Islam di Tengah Arus Globalisasi (Yogyakarta: Teras, 2010), 22-26

${ }^{6}$ Kebijakan Full Day School hanya berlangsung beberapa saat karena mendapat pertentangan luar biasa dari masyarakat penyelenggara dan pengelola pendidikan keagamaan. 
trend dalam kegiatan pembelajaran di sekolah-sekolah. Tumbuh berkembang juga proses pembelajaran dengan menambah kegiatan ekstra melalui pembelajaran baca tulis al-qur'an di sekolah.

Fakta lain menyebutkan, bahwa dinamika pondok pesantren dalam setiap periode kepemimpinan nasional selalu menarik perhatian bagi proses pembentukan kebijakan di Indonesia. Pembahasan pembentukan Sistem Pendidikan Nasional (SPN) sebagai keputusan politik, dari zaman Soekarno sampai zaman reformasi selalu mengalami suasana politik yang cukup menegangkan. Ketegangan itu terjadi manakala masuk pada materi pembahasan kedudukan pendidikan Islam, terutama menyangkut materi Pendidikan Agama Islam (PAI). Kesepakatan politik pasca reformasi yaitu dengan terbentuknya Undang-Undang Nomor 20 Tahun 2003 tentang Sistem Pendidikan Nasional juga berujung pada kompromi politik, sebagaiman terjadi pada zaman Soekarno. Pola dan konfigurasi politiknya memiliki kesamaan. Kelompok-kelompok poitik itu terfragmentasi dalam sekuler, nasionalis, dan religus.

Sebagai bentuk kompromi politik dalam pembentukan SPN, disebutkan dalam pasal 12 ayat (1) huruf a, yaitu setiap peserta didik pada setiap satuan pendidikan berhak mendapatkan pendidikan agama sesuai dengan agama yang dianutnya dan diajarkan oleh pendidik yang seagama. Dalam penjelasannya disebutkan, bahwa pendidik dan/atau guru agama yang seagama dengan peserta didik difasilitasi oleh Pemerintah atau Pemerintah Daerah sesuai kebutuhan satuan pendidikan sebagaimana diatur dalam pasal 41 ayat (3). Ketentuan dalam pasal ini dikatakan kompromi karena banyak pihak, baik kelompok parlemen maupun di luar parlemen. Setidaknya ada tiga kelompok yang berbeda pandangan dalam memposisikan Pendidikan Agama. Kelompok pertama menginginkan agar pendidikan agama tidak dimasukkan dalam kurikulum, pendidikan agama menjadi domain pemeluk agama yang diajarkan oleh masing-masing pemeluknya. Tempatnya bukan di sekolah atau perguruan tinggi, tetapi di tempat ibadah atau institusi keagamaan pemeluknya. Pemerintah hanya memberikan kebebasan kepada para pemeluknya, memfasilitasi berdirinya tempat ibadah, memberikan jaminan keamanan dan kenyamanan para pemeluk agama menjalankan kewajiban ajaran agamanya.

Setiap periode kepemimpinan politik di Indonesia selalu berhubungan dengan pondok pesantren sebagai institusi pendidikan Islam. Hubungan itu adalakalanya konfrontasi, namun di sisi lain juga melakukan kompromi. Dinamika pesantren dengan Negara memang selalu menarik perhatian, sistem pemerintahan dan sistem politik banyak 
memberikan kontribusi bagi keberlangsungan hubungan pesantren dengan Negara. Dinamika politik pesantren-negara mengalami pasang surut sejalan dengan dinamika politik. Diinternal umat Islam pun, hubungan Negara-pesantren mengalami perdebatan yang sangat tajam. Tidak jarang, sesama umat saling "menjatuhkan" hanya persoalan bagaimana formulasi bubungan itu. KH. Hasyim Asy’ari, sebagai figur ulama dan kiai yang mewakili pesantren pernah mendapat serangan politik yang dahsyat bagi kelompok Islam lainnya. Pemberitaan sebagai kiai yang pro penjajah pernah ditempelkan pada sosok sang kiai.

Pondok pesantren selalu mengalami perubahan dalam sistem penyelenggaraan. Dinamika sistem pendidikan nasional yang dibentuk oleh sistem politik selalu berkembang dan terus menyesuaikan dengan alam demokrasi. Sejak zaman penjajahan, masa kemerdekaan, sampai era sekarang, pasang surut pondok pesantren dalam pandangan negara mengalami dinamika yang cukup menegangkan. Sebagai lembaga pendidikan Islam, perkembangan pondok pesantren dalam sistem pendidikan nasional dan dinamika kebijakan politik kebangsaankenegaraan tidak berjalan dalam kotak yang tertutup, tapi telah berada dalam lapangan terbuka. Semua bisa berkepentingan dengan keberadaan pesantren, tidak sedikit yang memanfaatkan pesantren dalam kontestasi politik di Indonesia. Pesantren menjadi magnet tersendiri bagi proses penyelenggaraan Negara.

Pada pertengahan Oktober 2018, Dewan Perwakilan Rakyat Republik Indonesia (DPR RI) telah menetapkan Rancangan UndangUndang (RUU) tentang Pesantren dan Pendidikan Keagamaan sebagai pelaksanaan hak inisiatif. Dalam tulisan ini, penulis akan mengkaji RUU tersebut dalam perspektif para kiai dan pengelola pondok pesantren. Bagaimana mereka merespon RUU? Apakah ada keuntungan dan kerugian bagi pesantren jika RUU ditetapkan menjadu Undang-Undang? Dan analisis terhadap regulasi yang sudah berjalan sebelumnya serta teori kekuasaan.

\section{B. Materi Muatan RUU Pesantren dan Pendidikan Keagamaan}

Memahami materi rancangan undang-undang perlu memahami juga apa saja yang akan daitur di dalamnya. Semua yang menjadi materi dalam RUU, mulai dari judul sampai pasal penjelasan adalah satu kesatuan yang tidak terpisahkan. Banyak pakar menyatakan bahwa untuk memahami materi muatan dalam sebuah Undang-Undang, cukup memahami apa yang ada di dalam konsideran. Sebagaimana disebutkan dalam Undang-Undang yang mengatur Pembentukan Peraturan 
Perundang-undangan, bahwa materi dalam konsideran harus memuat landasan filosofis, sosiologis, dan yuridis.

Sebelum penulis menjelaskan beberapa materi muatan RUU Pesantren dan Pendidikan Keagamaan, penulis memberikan beberapa norma yang mengatur tentang cara dan metode pembentukan peraturan perundang-undangan. Ini penting untuk menjadi landasan dan cara memahami alur pembentukan peraturan perundang-undangan. Bagi kalangan praktisi dan pakar hokum tata Negara atau orang yang pernah terlibat secara aktif dan produktif, tidak mengalami kesulitan dalam memahami alur dan mekanisme pembentukan peraturan perundangundangan. Namun bagi kalangan akademisi yang berbasis ilmu-ilmu keislaman, agaknya belum membumi. Untuk itu, penulis akan menjelaskan secara singkat dan sederhan sesuai pengetahuan dan pengalaman menjadi nara sumber pada lembaga pembentuk peraturan perundang-undangan di daerah.

Para aktor kebijakan ${ }^{7}$ dalam membentuk peraturan perundangundangan harus merujuk pada regulasi yang mengatur tata cara pembentukan. Mengapa perlua diatur dalam pembentukan peraturan perundang-undangan? Konsideran huruf b Undang-Undang Nomor 12 Tahun 2011 tentang Pembentukan Peraturan Perundangan disebutkan, bahwa untuk memenuhi kebutuhan masyarakat atas peraturan perundang-undangan yang baik, perlu dibuat peraturan mengenai pembentukan peraturan perundang-undangan yang dilaksanakan dengan cara dan metode yang pasti, baku, dan standar yang mengikat semua lembaga yang berwenang membentuk peraturan perundang-undangan. Ini alas an sosiologis bagi setiap pembentuk perundang-undangan, kebakuan dan kepastian dalam tata cara dan metode menjadi penting agar setiap lembaga yang memilikik kewenangan membentuk peraturan perundangundangan tidak menjalankan kewenangannya sesuai dengan selera kekuasaan yang sedang didudukinya.

Dalam kontek rancangan undang-undangan tentang pesantren dan pendidikan keagamaan, materi muatan peraturannya tentu mengandung

${ }^{7}$ Istilah aktor kebijakan merujuk pada kajian yang membahas tentang kebijakan publik. Siapa saja yang disebut sebagai aktor atau pemeran serta dijelaskan oleh Budi Winarno dalam Kebijakan Publik: Teori, Proses, dan Studi Kasus (Yogayakarta: CAPS, Center of Academic Publishing Service, 2013). Dalam bukunya disebutkan, ada dua kelompok yang disebut sebagai aktor atau pemeran, yaitu pemeran resmi dan tidak resmi. Legislatif, Eksekutif, dan Yudikatif dikategorikan sebagai pemeran resmi. Sementara yang tidak resmi termasuk partai politik, warga Negara, dan kelompok kepentingan. Lebih luas baca dalam Budi Winarno pada halaman 125 sampai 145.

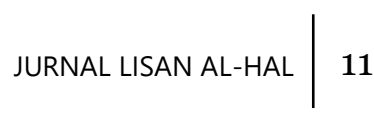


alasan filosofis, sosiologis, dan sangat mungkin ideologis menjadi pertimbangan. Agar pembaca menjadi paham, perlu penulis jelaskan definisi materi muatan perundang-undangan, yaitu materi yang dimuat dalam peraturan perundang-undangan sesuai dengan jenis, fungsi, dan hierarki peraturan perundang-undangan. ${ }^{8}$ Mengenai hierarki, disebutkan dalam pasal 7 UU Nomor 12 Tahun 2011, pada ayat (1) disebutkan; jenis dan hierarki peraturan perundang-undangan terdiri atas: a UndangUndang Dasar Negara Republik Indonesia Tahun 1945; b. Ketetapan Majelis Permusyawaratan Rakyat; c. Undang-Undang/Peraturan Pemerintah Pengganti Undang-Undang; d. Peraturan Pemerintah; e. Peraturan Presiden; f. Peraturan Daerah Provinsi; dan Peraturan Daerah Kabupaten/Kota. Selanjutnya dalam pasal 8 ayat (1) diatur, selain jenis peraturan perundang-undangan sebagaimana dimaksud pada pasal 7 ayat (1), diatur juga jenis peraturan yang ditetapkan oleh MPR, DPR, DPD, MA,MK, Badan Pemeriksa, Komisi Yudisial, Bank Indonesia, Menteri, Badan, Lembaga, atau komisi yang setingkat sampai struktur atau hierarki pemerintahan pada pemerintahan desa yang ditetapkan oleh Kepala Desa. $^{9}$

Untuk memahami maksud dan tujuan pembentukan rancangan undang-undang tentang pesantren dan pendidikan keagamaan, penulis akan menyebutkan beberapa materi yang dimuat dalam RUU. Namun perlu dijelaskan, bahwa RUU ini merupakan usul dari DPR RI. Kelompok pengusul itu diawali dan dimotori oleh dua fraksi yang berasal dari partai politik berbasis umat Islam (penulis tidak menyebutkan asas Islam), namun secara bulat semua fraksi menyetujui usul RUU Pesantren dan Pendidikan Keagamaan menjadi usul institusi lembaga DPR. Memang, untuk mengusulkan sebuah RUU harus ada kelompok atau perseorangan dari kalangan anggota DPR yang mengusulkan, sebagaimana diatur dalam Undang-Undang tentang Kedudukan MPR, DPR, DPD, dan DPRD. Dalam UUD Negara Republik Indonesia Tahun 1945 pasal 20 ayat (1) disebutkan DPR memegang kekuasaan membentuk undang-undang (perubahan pertama). Kemudian mengenai hak anggota dalam menyampaikan usul dijelaskan dalam pasal 20A UUD Tahun 1945.

8 Pasal 1 angka 23 Undang-Undang Nomor 12 Tahun 2011 tentang Pembentukan Peraturan Perundang-Undangan. Lihat Himpunan Peraturan Perundang-Undangan Republik Indonesia (Bandung: Nuansa Aulia,2011),4.

9 Para pembentuk undang-undang dalam menjalankan kekuasaannya diatur dalam Undang-Undang yang mengatur kedudukan dan kewenangannya, seperti Undang-Undang tentang Desa yang di dalamnya juga mengatur kewenangan dalam pembentukan peraturan desa.

12 JURNAL LISAN AL-HAL 
Ada lima pertimbangan dalam RUU Pesantren dan Pendidikan Keagamaan yang tertulis dalam konsideran. Penulis hanya mencantumkan dua konsideran yang memiliki landasan filosofis dan sosiologis, yaitu pada konsideran huruf b dan c, sebagai berikut:

b. bahwa salah satu upaya untuk meningkatkan keimanan dan ketakwaan serta akhlak mulia dilakukan melalui pendidikan keagamaan dan penyelenggaraan pesantren yang sudah tumbuh dan berkembang di masyarakat serta berkontribusi penting dalam melahirkan insan beriman yang berkarakter, cinta tanah air dan berkemajuan, serta terbukti berjasa dalam perjuangan kemerdekaan Indonesia, pergerakan kebangsaan maupun pembangunan nasional;

c. bahwa pesantren sebagai subkultur, memiliki kekhasan dan keunikan yang telah mengakar serta hidup dan berkembang di tengah-tengah masyarakat, baik sebagai lembaga pendidikan, lembaga penyiaran ajaran agama (dakwah Islam), dan sebagai lembaga pemberdayaan masyarakat, di mana dalam perkembangannya pesantren dan pendidikan keagamaan masih mengalami ketimpangan pada aspek pembiayaan, dukungan sarana prasarana, sumber daya manusia bermutu, dan kurangnya keberpihakan negara terhadap pesantren dan pendidikan keagamaan agar memiliki kompetensi dan keunggulan yang berdaya saing global;

Dua pertimbangan di atas, mencerminkan maksud dan tujuan dibentukanya RUU. DPR masih membaca, bahwa kenyataannya perlakuan Negara terhadap pesantren dan pendidikan keagamaan belum maksimal, bahkan terkesan menganaktirikan. Pernyatan politis DPR menyebutkan sebagai adanya ketimpangan dalam hal kebijakan anggaran yang kurang memadai terhadap pemenuhan penyelenggaraan pesantren dan pendidikan keagamaan. Akibatnya sarana dan prasarana, sumber daya manusia, dan segala sesuatu yang mendukung kelancaran proses penyelenggaraan pesantren dan pendidikan keagamaan tidak berimbang dengan kebutuhan dan tuntutan perkembangan zaman, kemajuan ilmu pengetahuan dan teknologi yang menjadi keniscayaan pertarungan global.

Setiap produk undang-undang harus menjelaskan terlebih dahulu apa saja yang akan diatur dalam materi muatan perundang-undangan. Biasanya dalam pasal 1, ketentuan umum menjelaskan satu persatu segala hal yang akan diatur dalam undang-undang. Untuk mengatur keberadaan pesantren, dalam RUU Pesantren dan Pendidikan Keagamaan, pasal 1 angka 1 menjelaskan definisi tentang pesantren. disebutkan sebagai berikut: 
Pondok Pesantren, Dayah, Surau, Meunasah, atau sebutan lain, yang selanjutnya disebut Pesantren adalah subkultur atau lembaga berbasis masyarakat yang didirikan dengan tujuan untuk menanamkan keimanan dan ketakwaan kepada Allah SWT, menyemaikan akhlak mulia, dan membentuk karakter pribadi yang senantiasa memegang teguh ajaran agama, merawat nilai luhur bangsa, dan memiliki orientasi menyelenggarakan pendidikan diniyah atau jenis pendidikan lain untuk mengembangkan kemampuan, pengetahuan, dan keterampilan masyarakat dan terutama peserta didik dalam memahami dan mengamalkan nilainilai ajaran agama dan/atau menjadi ahli ilmu agama, menggerakkan dan menyiarkan dakwah Islam rahmatal lil alamin, serta sebagai lembaga pemberdayaan sosial ekonomi masyarakat

Definisi tersebut hampir sama dengan apa yang dimaksudkan dalam Peraturan Menteri Agama Republik Indonesia Nomor 13 Tahun 2014 tentang Pendidikan Keagamaan Islam. Definisi dalam RUU memperluas apa yang dimaksudkan dalam PMA tersebut. Ada tambahan beberapa kalimat atau pernyataan tentang pesantren, seperti dikatakan sebagai sub kultur untuk mengistilahkan penyebutan lain pesantren. Kalimatnya tidak menggunakan diselenggaran masyarakat, tetapi berbasis masyarakat.

Dari keseluruhan pasal-pasal di RUU yang berjumlah 169, pasal yang mengatur tentang pesantren berjumlah 16 pasal, $3 \mathrm{bab}$, yang terbagi dalam bab ketentuan umum, bab asas, tujuan, dan ruang lingkup, dan bab penyelenggaraan pesantren. Untuk bab penyelenggaraan pesantren dibagi menjadi lima bagian, yaitu bagian pertama mengatur ketentuan umum, bagian kedua pendirian, bagian ketiga pesantren sebagai lembaga pendidikan, bagian keempat pesantren sebagai Lembaga Penyiaran Ajaran Agama (Dakwah Islam), dan bagian kelima Pesantren Sebagai Lembaga Pemberdayaan Masyarakat. dalam hal pengaturan tentang pesantren secara umum disebutkan dalam pasal 5 RUU, yaitu :

Keberadaan Pesantren harus memenuhi paling sedikit 5 (lima) persyaratan sebagai berikut: a. Kiai atau sebutan lain; b. Santri yang mukim di Pesantren; c. pondok atau asrama; d. masjid atau mushalla; dan e. kajian kitab kuning atau dirasah islamiyyah.

Ketentuan umum yang disebutkan dalam pasal 5 di atas sekaligus sebagai syarat pendirian pesantren. Materi muatan rancangan dalam pasal 5 tersebut sama dengan pasal 5 yang ada di PMA Nomor 13 Tahun 2014 tentang Pendidikan Keagamaan Islam. Secara teoritik juga sama dengan hasil penelitian yang dilakukan oleh Zamahsyari Dhofier dan Profil

14 JURNAL LISAN AL-HAL 
Pesantren Mu'adalah yang diterbitkan oleh Direktorat Pendidikan Keagamaan dan Pondok Pesantren, Departemen Agama. Selanjutnya disebutkan dalam pasal 6 ayat (1) RUU, yaitu Kiai atau sebutan lain sebagaimana dimaksud dalam Pasal 5 huruf a harus memiliki kompetensi ilmu agama yang dipersyaratkan merupakan lulusan Pesantren atau pendidikan tinggi agama Islam. Tidak sama dengan apa yang dimaksudkan dalam ketentuan pasal 1 angkat 7, yaitu Kiai, Tuan Guru/Gurutta/Inyiak, Syekh, Ajengan, Ustadz, Nyai, Ustadzah, atau sebutan lain adalah seorang pendidik yang memiliki kompetensi ilmu agama yang berperan sebagai figur, teladan, dan/atau pengasuh Pesantren. Pasal ini (6 ayat (1))mengatur persyaratan pendidikan seorang kiai, dan harus dinyatakan lulus. Tanda bukti lulus ini tentu harus dibuktikan dengan sesuatu yang bersifat nyata dan administratif. Mengacu pada pasal 6 PMA Nomor 13 Tahun 2014, tidak ada syarat kelulusan, yang ada seorang kiai wajib berpendidikan pesantren.

Secara umum, enam belas pasal yang ada dalam RUU Pesantren dan Pendidikan Keagamaan ada kesamaan pandangan dengan materi muatan yang diatur dalam PMA Nomor 13 Tahun 2014. Penulis tidak menyebutkan satu per satu keenam belas pasal tersebut. Pasal-pasal yang jadi kajian dalam penulisan ini berfokus pada ketentuan pasal yang berpotensi menimbulkan polemik dikalangan para kiai. Penulis menyebutkan "berpotensi" karena sejak bergulirnya RUU yang disetujui sebagai usul DPR, pada tanggal 16 Oktober 2018, banyak ragam pandangan yang sangat variatif. Pasal-pasal yang mengatur ketentuan tentang pendidikan keagamaan tidak penulis bahas dalam kajian ini, karena materi selain ketentuan pesantren tidak hanya mengatur tentang pendidikan keagamaan Islam, ada pengaturan pendidikan keagamaan Kristen, Katolik, Hindu, Buddha, dan Khonghucu.

\section{Perspektif Para Kiai}

Usul anggota DPR mengenai pengaturan pesantren dan pendidikan keagamaan, yang kemudian disepakati bersama sebagai usul kolektif institusi menjadi RUU Pesantren dan Pendidikan Keagamaan telah mengundang berbagai opini dan persepsi di kalangan masyarakat, terutama masyarakat pesantren. Persepsi tersebut sangat beragam di kalangan para penyelenggara pesantren. Ada yang menganggap bahwa RUU tersebut sebagai langkah politik Negara untuk memberikan ruang yang cukup bagi pesantren untuk berkiprah lebih luas dalam mengisi ruang publik dalam percaturan dan pertarungan global. Ada juga yang menganggap bahwa RUU Pesantren justru akan membelenggu pesantren. 
Anggapan yang kedua ini berpikir bahwa pesantren itu tidak perlu diatur secara resmi dan formal dalam sistem perundang-undangan. Kekhasan dan karakterisitk pesantren justru terletak pada "ketidak aturannya" dalam menyelenggarakan berbagai fungsinya; pendidikan, penyiaran ajaran Islam, pemberdayaan masyarakat, dan pembentukan budaya.

Selain dua anggapan tersebut di atas, RUU Pesantren dan Pendidikan Keagamaan juga dianggap oleh sebagian kalangan pesantren sebagai langkah maju penyelenggara Negara dalam hal "pemberian hadiah" kepada pesantren. Sebagaimana disebutkan dalam pertimbangan konsideran, bahwa salah satu alas an yang dibangun oleh anggota DPR dalam membentuk peraturan perundang-undangan tentang Pesantren dan Pendidikan Keagamaan adalah memberikan porsi berimbang dalam hal kebijakan anggaran. Selama ini pesantren mengalami perlakukan diskrimantif dalam hal pemerolehan anggaran yang bersumber dari keuangan Negara. Akibat perlakuan yang dirasa diskriminatif tersebut, sarana prasarana, sumber daya manusia, dan segala sesuatu yang berkaitan dengan pemenuhan kebutuhan pesantren mengalami ketimpangan dengan badan-badan publik penyelenggara pendidikan dan pemberdayaan masyarakat. Bagi kalangan pesantren dan pemerhati penyelenggaraan pendidikan pesantren, anggapan ketiga ini mengindikasikan sebagai bentuk kepedulian pemerintah bagi keberlangsungan pesantren.

Pemerintah harus punya perhatian lebih terhadap pesantren, kontribusi pesantren dan kiainya dalam hal tegaknya Negara Kesatua Republik Indonesia sudah sangat cukup untuk menjadi alas an pemerintah memajukan pesantren. Sejak reformasi bergulir dan adanya perubahan Undang-Undang Dasar Negara Republik Indonesia Tahun 1945 sampai empat kali, kebijakan terhadap penyelenggaraan pendidikan sudah sangat jelas, yakni sebesar 20 \% (dua puluh persen) dari Anggaran Pendapatan dan Belanja Negara/Daerah. ${ }^{10}$ Bersamaan dengan perkembangan zaman dan kemajuan teknologi, pesantren sudah sangat berkembang pesat. Penyelenggaraan pendidikan yang ada di pesantren bukan hanya berfokus pada kajian ilmu-ilmu keislaman, tetapi sudah merambag kea rah integrasi keilmuan. Karena itu, menjadi wajar dan seharusnya pemerintah dan Negara memberikan porsi yang cukup bagi penyelenggaraan pesantren.

10 Lihat UUD Negara Republik Tahun 1945 pasal 31 ayat (4), dan UU Nomor 20 Tahun 2003 tentang Sistem Pendidikan Nasional pasal 49. Ketentuan batasan 20 \% yang ada dalam UU Sisdiknas telah putuskan oleh MK menjadi keseluruhan APBN/APBD. Sebelumnya angka tersebut tidak memasukkan anggaran pegawai sebagai batasan tersebut.

16 JURNAL LISAN AL-HAL 
Anggapan atau persepsi lain, di kalangan kiai sebagai penyelenggara dan pemegang kekuasaan tertinggi di pesantren, kehadiran RUU ini justru menjadi bumerang bagi pesantren. Memperkuat "agresi" Negara dalam hal penyelenggaraan pesantren yang diungkapkan oleh para pemerhati dan sebagian masyarakat pesantren atas RUU Pesantren, sebagian kiai justru menolak kehadiran RUU ini. Alasan yang disampaikan para kiai adalah akan muncul intervensi berbagai hal yang berkaitan dengan proses penyelenggaraan dan pengelolaan pesantren. Bukan hanya sekedar memberikan bantuan sarana prasarana, tetapi lebih jauh Negara ${ }^{11}$ akan hadir untuk mengintervensi proses pendirian sampai penyelenggaraan sistem pembelajaran di pesantren. Proses, input, dan keluaran pesantren akan kehilangan jati dirinya sebagai lembaga yang telah lama berkembang di Indoensia dengan segala keunikan dan keragaman yang khas.

Tanggapan yang lebih akomodatif dan solutif diberikan oleh kelompok penyelenggara pesantren yang tergabung dalam Asosiasi Ma'had Aly Indonesia (AMALI). Mereka beberapa kali menyelenggarakan forum-forum kajian dan pembahasan kritis terhadap RUU Pesantren dan Pendidikan Keagamaan. Para kiai yang tergabung dalam AMALI bukan hanya membaca satu per satu atas materi muatan RUU Pesantren dan Pendidikan Keagamaan, namun memberikan tawaran materi muatan untuk dimasukkan dalam beberapa pasal di RUU. Selain itu, untuk memperkuat argumentasi tawaran itu, AMALI membuat matrik yang berisi materi mauatan RUU dan alasan-alasannya. Matrikulasi pembahasan dan kajian kritis kelompok AMALI tersebut dirumuskan dalam Daftar Inventarisir Masalah (DIM). Ini sungguh langkah maju, karena para kiai biasanya melakukan kajian keagamaan melalui forum bahsul masail yang argumentasinya diambil dari rujukan kitab kuning yang ditulis oleh para ulama salafus soleh.

Bukan hanya AMALI yang melakukan kajian kritis, dalam forum lain, AMALI juga mengajak kelompok Asosiasi Pendidikan Diniyah Formal (ASPENDIF). Seperti yang ditulis bloktuban.com, pada tanggal 18 September 2018, betempat di Ma'had Aly Al-Hasaniyyah Senori, Tuban, diselenggarakan forum kajian kritis terhadap RUU Pesantren dan Pendidikan Keagamaan. Para peserta diberi kesempatan untuk

11 Negara dalam konsep Max Weber dikatakan sebagai institusi politik yang memiliki otortas utama dalam membentuk undang-undang dan menggunakan instrumen kekuasaan politiknya untuk melakukan pemaksaan dalam lingkup wilayah geografis tertentu. Lihat Silvano Keo Bhaghi, Negara Bukan-Bukan? (Maumere: Ledalero, 2016), 8.

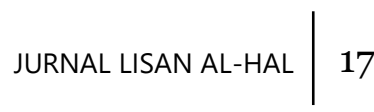


menyampaikan tanggapan kritis. Forum ini bertujuan untuk melakukan penyesuaian RUU dengan keberadaan pesantren yang sudah lama berdiri di Indonesia. Salah satu peserta dan sekaligus panitia, Zainudin menyatakan agar RUU Pesantren dan Pendidikan Keagamaan segera disahkan dalam waktu tidak terlalu lama. RUU ini sangat ditunggu kalangan pesantren dan penyelenggara pendidikan diniyyah, baik formal maupun nonformal.

Pesantren Salafiyah Syafi'iyah Sukorejo (Pesantren Sukorejo) sebagai bagian dari keseluruhan pesantren yang ada di Indoensia, tergugah untuk ikut terlibat dalam proses pembahasan dan pembentukan opini untuk kelanjutan RUU Pesantren dan Pendidikan Keagamaan. Melalui kebijakan KHR. Ahmad Azaim Ibrahimy, pengasuh keempat Pesantren Sukorejo disenggarakanlah forum Silaturahim ${ }^{12}$ Nasional (SILATNAS) yang melibatkan pengasuh-pengasuh pesantren di Indonesia. Forum ini merupakan bentuk keprihatinan dan kepedulian Pesantren Sukorejo atas nasib pesantren-pesantren di Indonesia. Bila ditilik dari perspektif individu, Pesantren Sukorejo yang sudah berusia lebih dari satu abad ini, keberadaan RUU tidak menjadi masalah. Ada atau tida ada peraturan perundang-undangan yang mengatur keberadaan pesantren, bagi Pesantren Sukorejo tetap eksis. Kepedulian dan keprihatian serta keberpihakan Pesantren Sukorejo menjadi alasan untuk menyelenggarakan SILATNAS.

Untuk mengantarkan forum SILATNAS, KH. Ahmad Azaim menyampaikan "pidato politik kebangsaan" agar forum in benar-benar menghasilkan produk ijtima' yang dapat dijadikan sebagai bahan pertimbangan para aktor kebijakan. Sebelum menyelenggarakan forum SILATNAS, Kiai Azaim sudah melakukan langkah-langkah strategis, yaitu membentuk tim kajian dan analisis terhadap RUU Pesantren dan Pendidikan Keagamaan. Rumusan tim inilah yang menjadi salah satu dokumen "pokok" dalam SILATNAS. Oleh karena itu, penulis menyampaikan gagasan pokok Kiai Azaim perlunya menyelenggarakan SILATNAS, yaitu:

1. Kita berkesimpulan bahwa apa yang telah diusulkan DPR melalui RUU sejatinya memiliki niat dan motivasi baik, yakni memberdayakan pesantren dan pendidikan keagamaan. Namun apa yang ada dalam

12 Pilihan kata "silaturahim" sebenarnya hanya untuk menguatkan keberadaan forum yang akan diikuti oleh para kiai. Di kalangan pesantren, kata silaturahim lebih popular daripada silaturahmi. Dalam kamus bahasa Indonesia, yang benar memang silaturahmi. Dengan alasan diplomatis dan taktis, panitia menyepakati penggunaan kata silaturahim. 
RUU, baik naskah akademik maupun materi muatan yang tertuang dalam RUU belum menunjukkan kesempurnaan niat baik. Ada banyak problem jika isi materi muatan yang ada dalam RUU disetujui bersama antara DPR dan Presiden. Untuk membahas lebih dalam terhadap keseluruhan materi muatan RUU, kami melakukan langkah, berkirim surat kepada Presiden, membentuk tim kajian, merencanakan kegiatan Silaturahim Nasional yang diikuti oleh pengasuh/pengelola pesantren dan pendidikan keagamaan se nusantara.

2. Untuk langkah pertama kami berkirim surat kepada Presiden RI yang pada pokokonya agar Pemerintah sebagai penerima usul RUU untuk lebih berhati-hati dalam mencermati setiap materi yang tertuang dalam RUU. Karena itu, kami minta kepada Presiden agar tidak tergesa-gesa memberikan tanggapan ke DPR. Pemerintah kami harap memberikan ruang komunikasi ke masyarakat, terutama penyelenggara pesantren dan pendidikan keagamaan untuk dimintai pemikiran, tanggapan, dan segala sesuatu berkaitan dengan kebaikan dan kesempurnaan RUU.

3. Dalam catatan kami, naskah akademik masih terdapat beberapa pokok materi yang belum sejalan atau sinkron dengan isi materi yang ada dalam RUU. Problem disparitas (jarak/ perbedaan) anggaran yang dikatakan sebagai tidak adil dalam memperhatikan keberadaan pesantren dan pendidikan keagamaan, menurut catatan kami belum dimunculkan secara konprehensip. Satu hal yang harus diingat, bahwa ada empat pokok masalah perlunya dibentuk RUU, salah satunya adalah untuk menyelesaikan suatu masalah yang berarti membenarkan keterlibatan Negara dalam menyelesaikan masalah tersebut. Jika pesantren dan pendidikan keagamaan diatur dalam Undang-Undang, itu artinya Negara boleh mengatur dengan segala regulasi yang merujuk pada UU. Temuan catatan itu seperti pada sub bab "penyelenggaraan", tidak memasukkan pesantren, tetapi fokus pada pendidikan keagamaan.

4. Materi muatan RUU harus dikaji ulang, bahkan kalau perlu dihapus. Pada konsideran, pernyataan pesantren dalam sejarah kebangsaan dan kenegaraan tidak munculkan sebagai pokok pikiran, tetapi lebih pada fungsi pesantren sebagai lembaga yang menyelenggarakan pendidikan, penyiaran Agama Islam, dan pemberdayaan umat. Jika yang dimaksud pemberian penghargaan Negara terhadap konstribusi pesantren dalam sejarah perjuangan kemerdekaan bangsa Indonesia, maka poin ini menjadi pernyataan kalimat yang pertama kali muncul. 
5. Mengenai beberapa pasal, misalnya pada bab ketentuan umum, ada yang harus disederhanakan kalimatnya, seperti definisi pondok pesantren, ${ }^{13}$ kiai, dan beberapa ketentuan lain. Fungsi pesantren dan pendidikan keagamaan masih dijadikan satu kesatuan, padahal pesantren dan pendidikan keagamaan, jika disatukan dengan pendidikan agama selain Islam tentu sangat berbeda, harus ada pemisahan fungsi. Secara keseluruhan, dalam pasal-pasal yang mengatur pesantren, perlu disempurnakan. Kemudian pada pengaturan pendidikan keagamaan (Islam), ada beberapa materi yang memang seharus dihapus, disempurnakan, atau diganti. Sebagai bahan pertimbangan dan tambahan pembahasan dalam forum ini, kami sertakan hasil kajian bersama dengan RUU. ${ }^{14}$

Baik yang optimis, pesimis, dan berdiri diantara keduanya, keberadaan RUU Pesantren dan Pendidikan Keagamaan menjadi penting untuk dikaji lebih mendalam. Kajian dimaksud agar para kiai menjadi lebih tahu dan ikut berproses dalam memperhatikan RUU yang pada akhirnya akan menjadikan pesantren sebagai obyek pelaksanaan undangundang. Di forum SILATNAS bahkan ada yang menyampaikan terima kasih kepada dua fraksi partai politik di DPR yang telah memotori RUU ini. Para kiai sebenarnya tidak terlalu berkepentingan jika pesantren akan menjadi undang-undang yang akan berujung pada delegimitasi pesantren. Sebagian mengkhawatirkan keberadaan RUU jika pemegang kekuasaan akan mengintervensi proses penyelenggaraan pesantren.

\section{Analisis Kebijakan Publik dan Teori Kekuasaan \\ 1. Konsepsi Kebijakan dan Kekuasaan}

Sebelum masuk pada kajian analisis, penulis perlu menjelaskan dua kata yang akan menjadi basis kajian, yaitu kebijakan dan kekuasan, baik secara etimologi maupun terminology. Kebijakan publik secara etimologis dalam bahasa Inggris, berasal dari kata "Public Policy". Namun ada juga

\footnotetext{
13 Mengenai definisi pondok pesantren, para kiai yang ikut silatnas, menyampaikan gagasan konkrit agar memasukkan ajaran Islam ahlus sunnah wal jama'ah sebagai bagian penting dalam inti pokok pondok pesantren. Para kiai dari Nangro Aceh Darussalam (NAD) secara tegas dan tertulis menyampaikan usul konkritnya. Mengapa harus Aswaja? Karena semua pondok pesantren di Indonesia pasti mengajarkan aswaja, bila ada yang lain, itu pasti bukan pondok pesantren.

14 Apa yang disampaikan KH. Ahmad Azaim merupakan teks pengantar forum silatnas, sekaligus menyatakan kepada forum para pengasuh dan kiai-kiai yang hadir, bahwa Pesantren Sukorejo ikut peduli dan prihatin jika pondok pesantren yang sudah lama berdiri dan mengakar di Indonesia harus berada dalam sub ordinasi kekuasaan yang hegemonic.
}

20 JURNAL LISAN AL-HAL 
yang menerjemahkan menjadi "kebijaksanaan", seperti yang ditulis Abdul Wahab dan Solihin. ${ }^{15}$

Meskipun belum ada "kesepakatan", apakah policy diterjemahkan menjadi "Kebijakan" ataukah "kebijaksanaan", akan tetapi tampaknya kecenderungan yang yang ada, kata policy sering digunakan untuk menterjemahkan kata kebijakan. Nampaknya semua ilmuwan ada ijmak dan mufakat.

Dari telusur penulis, memang ada perbedaan antara kebijakan dan kebijaksanaan. Sebagaimana dalam bahasa Inggris, kebijakan berasal dari kata policy, sementara kata kebijaksanaan berasal dari kata wisdom. Menurut kamus bahasa Arab, ada dua kata yang sering digunakan dalam kajian kebijakan, yaitu تحكم dan سياسي. Kata yang pertama mengandung kebijakan yang ada dalam wilayah politik, sementara kata kedua bukan hanya persoalan politik, tetapi semua proses politik dan hukum harus tercermin sikap حكة , sebagai bentuk tunggal dari kata tahakum. Penulis mendapat saran dua kata tersebut dalam versi bahasa Arab saat ujian disertasi.

Jika demikian, kebijakan tidak bisa disamakan dengan kebijaksanaan. Namun satu hal yang perlu menjadi catatan, bahwa dalam proses kebijakan harus disertai dengan sikap kebijaksanaan. Sebagaimana tercermin dalam sila keempat Pancasila; "kerakyatan yang dipimpin oleh hikmah/kebijaksanaan dalam permusyawaratan/perwakilan". Sila mengandung makna, setiap proses pengambilan keputusan sebagai produk kebijakan yang dilakukan dalam system perundangundangan/hokum di Indonesia (tertulis/ tidak) harus sejalan dengan sikap kebijaksanaan. Bentuk dan mekanisme kebijaksanaan itu terwujud dalam lembaga-lembaga penyelenggara Negara. Pun demikian di DPR, sebagai aktor kebijakan publik, seluruh anggota DPR tidak semata-mata menjalankan kekuasaannya melalui cara-cara politik. Ada sikap yang harus ditunjukkan kepada public/rakyat dalam setiap proses menjalankan kekuasaan yang telah diamanatkan dari rakyat melalui sistem pemilihan umum. Menurut Kaelan, proses pengambilan kebijakan yang kering dari kebijaksanaan hanya sebuah formalisasi sistem saja. Untuk itu, Pendidikan Pancasila membahas tema etika yang berisikan nilai, norma, dan moral yang semuanya cerminan dari sikap kebijaksanaan dalam proses penyelenggaraan pemerintahan dan kenegaraan. ${ }^{16}$

15 Abdul Wahab, Solichin, Analisis Kebijaksanaan: Dari Formulasi Ke Implementasi Kebijaksanaan Negara, Edisi Kedua (Jakarta: Bumi Aksara, 2001)

16 Kaelan, Pendidikan Pancasila (Yogyakarta: Paradigma, 2004), 85-96

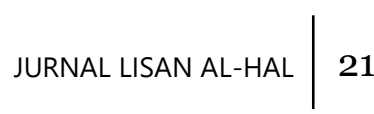


Secara paradigmatik-teoritik, kebijakan dapat diartikan sebagai prinsip atau cara yang dipilih untuk digunakan dalam proses pengambilan keputusan. Disebut prinsip karan mengandung unsur-unsur idelogi dan filosofi. Ealau dan Prewitt, sebagaimana tulis Edi Sharto, mendefinisikan kebijakan sebagai ketetapan yang bercirikan konsistensi dan berkesinambungan perilaku dalam pemberlakuannya, baik pembuat kebijakan maupun mereka yang menataatinya. Dengan demikian, kebijakan menurut rumusan Edi Suharto, sebagaimana pendapat Titmuss, Ealau, dan Prewitt adalah ketetapan yang memuat prinsip-prinsip untuk mengarahkan cara bertindak yang disusun secara terencana, konsisten, dan bermuara pada pencapaian tujuan. ${ }^{17}$

Dalam pandangan Tilaar, kebijakan dikategorikan sebagai fakta strategis daripada fakta politis dan teknis. Dikatakan strategi, kebijakan publik sudah terangkum preferensi-preferensi politis para aktor yang terlibat dalam proses perumusan kebijakan. ${ }^{18}$ Menurut William N. Dunn, kebijakan publik merupakan daftar pilihan berbagai tindakan aktor di dalam suatu institusi atau pemerintahan, yang satu sama lain saling berkaitan. ${ }^{19}$ Kebijakan bukan hanya sekedar pilihan tindakan, strategi dan perencanaan yang harus dilakukan aktor kebijakan, dengan tujuan mengatasi masalah sebagai kebutuhan pemenuhan kesejahteraan rakyat. ${ }^{20}$

Definisi etimologis dan terminologi di atas dapat "disepakati", bahwa kebijakan merupakan proses yang di dalamnya berisikan berbagai pilihan tindakan pengambilan kebijakan melalui perencanaan, strategi, dan gerakan politik. Apa yang dilakukan aktor dan pejabat pemerintahan atau badan-badan publik bertujuan memecahkan suatu masalah sekaligus sebagai solusi pemenuhuan kesejahteraan rakyat. Proses-proses itu harus dibarengi dengan sikap bijaksana sehingga lahir produk kebijakan yang benar-benar berwatak kebijaksanaan.

Setelah penulis menelusuri kebijakan dalam perspektif teoritik akademik, kajian selanjutnya adalah tentang kekuasaan sebagai arah analisis untuk mengetahuai arah RUU Pesantren dan Pendidikan Keagamaan.

Kekuasaan sering digunakan dalam literatur kepemimpinan dan manajamen, dalam konteks ini kekuasaan identik dengan power, Inggris.

\footnotetext{
17 Edi Suharto, Analisis Kebijakan Publik (Bandung: Alfabeta, 2010), 7

18 H.A.R. Tilaar dan Riant Nugroho, KebijakanPendidikan(Yogyakarta: PustakaPelajar, 2009), 185.

${ }^{19}$ William Dunn N, Analisis Kebijakan Publik (Yogyakarta: Gadjah Mada University Press, 2003), 132.

${ }^{20}$ Edi Suharto, Analisis Kebijakan Publik (Bandung: Alfabeta, 2010), 10.

22 JURNAL LISAN AL-HAL
} 
Hubungan dengan kepemimpinan, kekuasaan berjalan beriringan dengan adanya pengaruh (influence) dan wewenang (authority). Perbedaan antara kekuasan dan wewenang adalah kekuasaan dijalankan dengan kemampuan, sedang wewenang merupakan hak untuk melakukan langkah-langkah mengambil tindakan. Karena itu, penggunaan kekuasaan oleh seseorang dalam kepemimpinannya dilakukan untuk mempengaruhi orang atau kelompok lain agar mengikuti keinginannya dalam perubahan perilaku. Harapannya, setelah berubah maka kekuasan akan efektif sebagai sumber seseorang mendapatkan haknya dalam pusaran kekuasaannya. ${ }^{21}$

Dalam pandangan Michel Foucault, kekuasaan memiliki keterkaitan erat dengan pendidikan. Bagi Foucault, kekuasaan akan menghasilkan sebuah pengetahuan. Hubungan itu dapat dilihat melalui peran bahasa sebagai artikulasi dari kekuasaan. Bukan hanya itu, bahasa memiliki powerfully propaganda dan wacana. ${ }^{22}$ Konsepsi kekuasaan dalam perspektif Foucault bersifat orisinil dan realistis, titik tekannya adalah bagaimana kekuasaan itu dijalankan, diterima, dan dipandang sebagai kebenaran yang bermanfaat dalam berbagai bidang kehidupan. Soal hubungan kekuasaan, Habermas menghubungkan dengan politik, keduanya menempatkan bahasa dalam pola komunikasi, diskursif, dan kritis di tengah kehidupan sosial. ${ }^{23}$

Dalam dimensi kehidupan sosial, ada berbagai kelompok yang satu sama lain akan melakukan persaingan, sehingga untuk itu, kelompok dalam sosial saling mempenaruhi dengan menggunakan kekuasaanya. Karena itulah, kelompok yang satu akan mendominasi kelompok lain melalui pengelolaan kekuasaan. ${ }^{24}$ Ini dari kekuasaan dalam konteks kehidupan sosial adalah adanya hubungan interdependensi (saling mempengaruhi/ saling membutuhkan) untuk menampilkan eksistensi dirinya di tengah interaksi sosial. Agar interaksi dalam kehidupan sosial berjalan secara seimbang, kehadiran control sosial menjadi sebuah keniscayaan. Keseimbangan sosial menjadi lebih penting ketika penggunaan kekuasaan antar kelompok berlangsung dalam suasana distabilitas. Pandangan tersebut memiliki makna, bahwa seseorang atau

${ }^{21}$ Husaini Usman, Manajemen: Teori, Praktik, dan Riset Pendidikan (Jakarta: Bumi Aksara, 2013), 416-417.

22 Michael Foucault, Wacana Kuasa/Pengetahuan (Yogyakarta: Bentang Budaya, 2002), 20.

${ }^{23}$ Haryatmoko, Etika Politik dan Kekuasaan (Jakarta: Kompas, 2003), 22.

24 Zainuddin Maliki, Rekontruksi Teori Sosial Modern (Yogyakarta: UGM Press, 2012), 281.

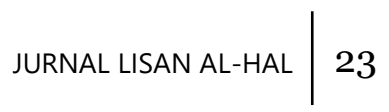


kelompok berpotensi memperoleh, memelihara, mempertahankan, dan merebut kembali kekuasaan. Lalu darimana memperoleh kekuasaan itu?

Berkaitan dengan sumber-sumber kekuasaan, Max Weber tiga tipe ideal sumber legitimasi kekuasaan, yaitu kekuasaan yang bersumber dari tradisi, kharisma, dan legal rasional. Masing-masing tipe itu dapat digambarkan, a) tipe tradisional memiliki keterkaitan dengan praktik pensucian tradisi dan kebiasaan yang sudah lama berakar, b) tipe kharismatik berpusat pada praktik kekuasaan atas dasar keunggulan atau keistimewaan yang dimiliki seseorang karena kekuatan magnetiknya, dan c) tipe legal rasional, setiap orang atau kelompok elit yang akan mendapatkan kekuasan harus mengikuti aturan sebagai sarana memperoleh kekuasaan. Tipa ketiga ini, dalam konteks sistem polilitik di Indonesia, dan Negara-negara demokrasi di dunia adalah mereka yang ada dalam pemerintahan; legislatif, eksekutif, dan yudikatif. ${ }^{25}$

Sosiolog Bertrand Russel memandang ada dorongan nafsu ingin berkuasa, yaitu eksplisit, dorongan yang dilakukan oleh seorang pemimpin, sementara implisit berada pada posisi manusia yang ingin dimpimpin. Sama halnya dengan Weber, Russel membagi kekuasaan ke dalam beberapa tipe, yaitu; pertama, kekuasaan tradisional, yakni kekuasaan yang didasarkan pada kepercayaan atau tradisi yang mencakup nilai-nilai religius dan kekuasaan yang dimiliki oleh seorang raja. Kedua, kekuasaan revolusioner, yakni kekuasaan yang berpusat pada suatu kelompok besar yang dibangun oleh adanya kepercayaan, program, atau adanya persamaan diantara kelompok, seperti Protestanisme, Komunisme. Ketiga, kekuasaan tanpa persetujuan. Yakni kekuasaan yang dimiliki oleh seseorang atau kelompok dengan menundukkan pengikutnya melalui cara-cara yang memberikan rasa takut, bukan dengan bekerja sama. Contoh kekuasaan tanpa persetujuan adalah kekuasaan yang dilakukan oleh sekelompok pemberontak. ${ }^{26}$

Sebagaimana diatur dalam undang-undang, DPR memiliki tiga fungsi, yaitu fungsi legislasi (membentuk undang-undang), anggaran (pembahasan untuk memberikan persetujuan atau tidak terhadap rancangan undang-undang tentang Anggaran Pendapatan dan Belanja Negara/APBN yang diajukan Presiden), dan fungsi pengawasan (mengawasi pelaksanaan undang-undang dan APBN). RUU Pesantren dan Pendidikan Keagamaan adalah bentuk nyata DPR melaksanakan fungsi

25 Ibid, 283.

${ }^{26}$ Damsar, Pengantar Sosiologi Politik (Jakarta: Kencana, 2015), 71.

$24 \mid$ JURNAL LISAN AL-HAL 
legislasi sebagai tindak lanjut penggunaan kekuasaan yang diperoleh melalui proses legal rasional.

Fungsi legislasi DPR dilaksanakan berdasarkan ketentuan peraturan perundang-undangan, baik undang-undang yang berkaitan dengan kedudukan DPR maupun undang-undang yang berkaitan dengan pembentukan peraturan perundang-undangan. Tidak serta merta DPR mengusulkan RUU hanya dilakukan melalui penggalangan tanda tangan yang dilakukan oleh anggota DPR. Ada proses dan prosedur yang harus dilalui, diantaranya harus ditetapkan terlebih dahulu sebelum masuk pembahasan ke dalam Program Legislasi Nasional (Prolegnas). Untuk memahami alur dan tahapan proses pembentukan kebijakan politik yang dilakukan oleh lembaga DPR, penulis menjelaskan beberapa poin penting secara teoritik dalam perspektif kebijakan politik. ${ }^{27}$

\section{Tahap-Tahap Kebijakan Publik dalam Pembentukan Undang- Undang}

William Dunn, ${ }^{28}$ membagi tahapan menjadi lima tahapan, yaitu; (i) tahap penetaapan agenda, (ii) tahap formulasi kebijakan, (iii) tahap adopsi kebijakan, (iv) tahap implementasi kebijakan, dan (v) tahap evaluasi kebijakan. Tahap-tahap kebijakan publik tersebut dapat dijelaskan sebagai berikut:

\section{a. Penetapan Agenda}

Para aktor kebijakan yang telah menempati posisi kekuasaan politik, dengan kewenangannya, mereka bekerja dalam pembentukan kebijakan dimulai dari menempatkan masalah pada agenda publik. Berbagai masalah yang telah dirangkum, sebagai hasil dari dengar pendapat dan jaring aspirasi, dirumuskan dan direduksi dalam satu dokumen, yaitu dokuman daftar inventarisir masalah. Satu persatu masalah akan berkompetisi untuk bisa masuk dalam sebuah agenda publik. ${ }^{29}$ Karena alasan tertentu, bisa saja masalah-masalah publik tidak

27 Secara khusus, Undang-Undang Nomor 12 Tahun 2011 tentang Pembentukan Peraturan Perundang-Undangan mengatur beberapa ketentuan tahapan, prosedur, bentuk, jenis, dan tata cara pembentukan undang-undang.

${ }^{28}$ William Dunn, Analisa Kebijakan Publik (Yogyakarta: Gajah Mada Press, 1999), 24 25. Lihat juga Budi Winarno, Kebijakan Publik; Teori, Proses, dan Studi Kasus (Jakarta: CAPS, Center of Academic Publishing Service, 2014), 35-37.

${ }^{29}$ Menyusun agenda adalah sesuatu yang sangat urgen karena para pemegang kebijakan akan memulainya dengan terlebih dahulu melihat daftar masalah. Bukan sekedar menetapkan agenda yang akan dilaksakan tetapi justru lebih dari itu. Ada dua penetapan agenda, yakni

$$
\begin{array}{l|l}
\text { JURNAL LISAN AL-HAL } & 25
\end{array}
$$


bisa masuk dalam agenda kebijakan publik. Masalah yang tidak masuk dalam tahap agenda, akan diagendakan pada pembahasan yang akan datang, itu pun bila secara politik memungkinkan. Konfigurasi politik dan kerja-kerja politik akan mendominasi pengaruh kekuasaan dalam menjalankan hak kewenangannya. Banyak item masalah belum tentu menjadi agenda yang ditetapkan selama belum menjadi perhatian serius para aktor kebijakan. Leo Agustino, ${ }^{30}$ mengutip Roger Cobb dan Charles Elder, membedakan agenda kebijakan menjadi dua tipe mendasar, yaitu agenda sistemik dan agenda institusional. Pertama, dikatakan agenda sistemik karena posisi masalah yang memang menjadi perhatian serius dalam kelompoknya. Agenda sistemik berada pada level sistem politik dan kewenangan sah. Sementara agenda intitusional adalah agenda yang berada pada institusi yang lebih spesifik dan konkret.

\section{b. Formulasi Kebijakan}

Fase atau tahap formulasi ini sangat fundamental dalam perumusan kebijakan publik. Arahnya agar tepat, benar, dan sesuai dengan apa yang menjadi harapan perumusan kebijakan. Perlu menjadi perhatian serius dan hati-hati ketika memformulasikan kebijakan publik, hasil akhir dari perumusan kebijakan publik akan menjadi pintu masuk dan penting untuk menyelesaikan suatu masalah. Pada tahap formulasi ini, Dunn membagi menjadi beberapa fase, yaitu fase pencarian masalah (problem search), pendefinisian masalah (problem specification), dan problem pengenalan (problem sensing). ${ }^{31}$ Alternatif beberapa masalah yang telah dipilih sebagai agenda prioritas, selanjutnya dicarikan formulasi alternatif pemecahannya. Pada tahap ini, para aktor satu sama lain akan melakukan lobi-lobi untuk menjadikan masalah prioritas masuk dalam formulasi problem solving. Disinilah para pengambil kebijakan akan "bermain" untuk menentukan mana yang terbaik dan memungkinkan mana yang akan digoalkan (mencapai kesepakatan).

sistematika agenda sebagai issu politik yang telah dipersepsi oleh masyarakat, dan institusional agenda untuk menentukan beberapa item yang secara eksplisit menjadi pemikiran serius dalam proses pembuatan keputusan. Lihat Nanang Fatah, Analisis Kebijakan Pendidikan (Bandung: Remaja Rosda Karya, 2012), 23.

30 Leo Agustino, Dasar-Dasar Kebijakan Publik (Bandung: Alfabeta, 2008), 105-106.

31 William Dun, Pengantar Analisa Kebijakan Publik (Yogyakarta: Gadjah Mada University Press, 1999), 97. Untuk memahami dasar-dasar kebijakan publik pada tahap formulasi kebijakan, Lihat Leo Agustino, 96-137.

26 JURNAL LISAN AL-HAL 


\section{c. Adopsi Kebijakan}

Ketika suatu agenda sudah dipilih sebagai alternatif pemecahan masalah untuk dijadikan agenda pembahasan, para aktor kebijakan akan memasukkan salah satu agenda untuk diadopsi dan didukung oleh seluruh aktor yang terlibat dalam pengambilan keputusan. ${ }^{32}$ Ketika sudah masuk pada tahap ini, para aktor akan bertarung untuk memasukkan agenda kebijakan sebagai alternatif yang tepat untuk memecahkan masalah. Maka menurut Winarno menjadikan tahap ini sebagai tahap pemilihan alternatif. 33 Synder, sebagaimana tulis Varma menyebutkan ada tiga proses dalam pembentukan keputusan, yaitu bidang kemampuan, komunikasi dan informasi, serta motivasi. ${ }^{34}$

\section{d. Implementasi Kebijakan}

Hal penting sebelum kebijakan diimplementasikan adalah penetapan kebijakan agar bisa dijadikan dasar hukum dalam melaksanakan apa yang menjadi ketentuan penyelesaian masalah. Tahap implementasi ini adalah tahap pendistribusian kebijakan yang akan dilaksanakan oleh personalia dalam unit-unit organisasi (pemerintah atau badan publik) yang digerakkan melalui sumberdaya finansial dan manusia. Membutuhkan adanya dukungan pelaksana, karena sangat dimungkinkan dalam situasi tertentu akan mendapatkan pertentangan diantara para pelaksana.. Untuk memenuhinya, Van Meter dan Van Horn menawarkan enam variabel model implementasi kebijakan yang satu sama lain membentuk kaitan (linkage) antara kebijakan dan kinerja (performance). Enam variabel tersebut adalah a) ukuran dasar dan tujuan, b) sumber-sumber kebijakan, c) komunikasi antar organisasi dan kegiatan,

32 Sebenarnya, pengambilan keputusan merupakan kegiatan sehari-hari yang biasa dilakukan oleh setiap individu. Hanya saja, keputusan yang dilakukan sendiri dampaknya tidak meluas, hanya dirasakan sendiri oleh individu yang telah membuat keputusan. Kalau keputusan tersebut terpaksa menyertakan pihak lain maka tidak sebanyak yang ditimbulkan oleh pengambilan keputusan yang dilakukan oleh seorang pemimpin. Untuk itu, aktor dalam pengambilan keputusan haruslah mendahulukan kepentingan lintas kelompok tidak memihak kepada kelompoknya. Pemimpin publik harus banyak mendengarkan dan memperhatikan kepentingan banyak orang. Seandainya pun pemimpin memberikan keputusan sendiri, tetap ia harus memperhatikan banyak orang. Lihat Miftah Toha, Birokrasi Pemerintah dan Kekuasaan di Indonesia (Yogyakarta: Matapenan Institute, 2012), 187-88.

${ }^{33}$ Budi Winarno, Kebijakan Publik; Teori, Proses, dan Studi Kasus (Jakarta: CAPS, Center of Academic Publishing Service, 2014), 124.

${ }^{34}$ Kerangka pembuatan keputusan itu meliputi banyak proses sosial, politik maupun psikologis para aktor pengambil keputusan, lihat S.P. Varma, Teori Politik Modern (Jakarta: Rajagrafindo Persada, 2010), 393. 
d) karakteristik badan pelaksana, e) kondisi ekonomi, sosial, dan politik, dan f) kecenderungan pelaksana (implementor). Selain itu variabel, Meter dan Har, sebagaimana tulis Winarno menambah kapasitas sebagai variabel penting dalam implementasi kebijakan. ${ }^{35}$

\section{e. Evaluasi Kebijakan}

Pembentukan kebijakan pada dasarnya dilakukan untuk memecahkan masalah, yaitu mencapai kesejahteraan bersama. Agar dalam pelaksanaan dan proses kebijakan sesuai dengan apa yang menjadi harapan bersama, perlu adanya evaluasi. Ada dua hal yang harus dilakukan dalam proses evaluasi, yaitu 1) evaluasi internal, proses evaluasi yang hanya melibatkan pelaksana kegiatan melalui prosedur dan mekanisme yang sangat formal. 2) evaluasi eksternal, melibatkan orang lain atau lembaga di luar pelaksana kebijakan, biasanya melibatkan lembaga non pemerintah yang biayanya disponsori sendiri. Menurut Anderson, sebagaimana tulis Winarno, bahwa kegiatan evaluasi bukanlah akhir dari seluruh kegiatan dalam proses kebijakan publik. Evaluasi juga bekaitan dengan estimasi atau penilaian yang meliputi substansi, implementasi, dan dampak (outcome). Karena itu, evaluasi dilakukan dalam keseluruhan proses kebijakan yang dimulai dari perumusan masalah, usulan program, implementasi, dan dampaknya bagi penerima manfaat. ${ }^{36}$

Ada versi lain untuk membedakan klasifikasi tahap kebijakan publik, sebagaimana disebutkan oleh Husaini Usman, yaitu (1) pengenalan, penentuan, dan diagnosis suatu masalah; (2) pengembangan alternatif bagi pemecahan masalah; dan (3) evaluasi yang dibarengi dengan memilih berbagai alternatif pemecahan masalah. ${ }^{37}$ Seluruh tahapan dalam proses kebijakan sebenarnya memiliki substansi yang sama, yakni pemenuhan atas hidup sejahtera dan keadilan dalam rangkaian kehidupan sosial. Apa pun system politik dan pemerintahan yang dibangun oleh suatu Negara, muaranya adalah pencapaian kesejahteraan. Pun demikian dalam sistem totaliter yang dianut dalam kerajaan diberbagai dunia, semuanya jatuh pada muara kebahagiaan. Namun tidak sedikit Negara dengan sistem diktatornya membuat

\footnotetext{
35 Penjelasan lebih rinci tentang model implementasi van Meter dan van Horn baca dalam Budi Winarno, Kebijakan Publik: Teori, Proses, dan Studi Kasus (Yogyakarta: Center of Academic Publishing Service, 2014), 158-175.

${ }^{36}$ Ibid., 229

${ }^{37}$ Husaini Usman, Manajemen: Teori, Praktk, dan Riset Pendidikan (Jakarta: Bumi Aksara, edisi keempat, 2013),441.

28 JURNAL LISAN AL-HAL
} 
psikologi rakyat ketakutan luar biasa, ${ }^{38}$ sehingga kreatifitas dan inovasi hanya dimiliki oleh pemegang kebijakan yang terkumpul dalam aktoraktor kebijakan.

Untuk menganalisis kebijakan, baik proses perumusan maupun pelaksanaan, hal penting yang harus diperhatikan adalah mengetahuai model-model kebijakan. Ada beberapa model kebijakan, yang paling sering dijadikan bahan analisis kebijakan adalah model deskriptif dan normati. Menurut Dunn, model deskriptif dijadikan sebagi basis analisis untuk memprediksi pilihan alternatif pemecahan masalah yang sudah masuk pada tahap perumusan dan formulasi kebijakan. Sedang model normatif, selain melakukan peramalan/prediksi, juga memberikan pertimbangan rasional atas alternatif pemecahan masalah. Pertimbangan rasional itu berupa dalil-dalil yang dijadikan dasar dalam proses pembentukan kebijakan. ${ }^{39}$

\section{Analisis Kebijakan}

Mencermati proses pembentukan Rancangan Undang-Undang tentang Pesantren dan Pendidikan Keagamaan yang telah diajukan DPR sebagai hak usul RUU, penulis perlu menganalisis melalui pendekatan tahap dan model kebijakan. Materi muatan RUU itu memang terdiri dari dua pengaturan, yaitu pengaturan tentang pesantren dan pendidikan keagamaan. Sejatinya regulasi yang mengatur keduanya sudah dilakukan oleh Kementerian Agama Republik Indonesia. Ketentuan yang dibentuk oleh Kemenag tidak lepas dari rujukan sistem pendidikan nasioan, melalui Undang-Undang Nomor 20 Tahun 2003 tentang Sistem Pendidikan Nasional, khususnya ketentuan yang mengatur pendidikan agama dan keagamaan.

Tahap pembentuan RUU di DPR, secara prosedural sudah dilakukan melalui tahap penetapan program legislasi nasional (prolegnas). Proses penyusunan prolegnas merupakan perintah dari undang-undang yang mengatur tentang Pembentukan Peraturan Perundang-Undangan. Dalam tahap ini, para anggota DPR "berlomba dan bermain" untuk memasukan agenda permasalahan yang menurutnya dianggap penting dan dapat dijadikan sebagai alat pemecahan masalah. Setelah prolegnas, tahap selanjutnya adalah prosedur pengajuan usul draft RUU yang menjadi domain hak setiap anggota DPR. Sebagaimana kita ketahui, bahwa RUU

${ }^{38}$ Negara yang membuat rakyat terbungkam, salah satunya adalah Korea Utara.

39 William N. Dunn, Pengantar Analisis Kebijakn Publik, edisi kedua (Yogyakarta: UGM Press, 2003), 235-235.

\begin{tabular}{l|l} 
JURNAL LISAN AL-HAL & 29
\end{tabular} 
Pesantren dan Pendidikan Keagamaan diajukan oleh dua Fraksi di DPR, yaitu Fraksi PKB dan Fraksi PPP. Dua fraksi tersebut memang fraksi yang berlatar belakang dari basis konstituen masyarakat pesantren dan penyelenggara pendidikan keagamaan. Maka wajar dan seharusnya dua fraksi tersebut berjuang mengajukan usul rancangan undang-undang.

Setelah syarat ketentuan pengajuan usul RUU dipenuhi, selanjutnya diajukan ke pimpinan DPR untuk diagendakan dalam tingkat pembahasan, dan terakhir adalah tingkat pembahasan yang dilakukan dalam rapat paripurna untuk menyetujui atau tidak terhadap RUU yang telah diajukan oleh anggota DPR. Tepat pada tanggal 16 Oktober 2018, DPR menyetujui usul anggota DPR mengenai RUU Pesantren dan Pendidikan Keagamaan. Materi muatan dalam RUU tersebut bukan hanya berupa ketentuan pengaturan yang disebutkan dalam pasal per pasal, tetapi harus dilandasi oleh kajian akademik melalui dokmen naskah akademik. Keputusan resmi RUU tersebut kemudian diserahkan kepada Pemerintah untuk dimintakan pendapat. Selanjutnya pemerintah melalui Kemenag melakukan kajian yang dituangkan dalam Daftar Inventarisir Masalah (DIM).

Persetujuan DPR atas RUU tersebut kemudian megundang berbagai opini dan pandangan yang beragam. Setidaknya, menurut pengamatan penulis, ada tiga kelompok masyarakat yang memiliki pandangan beragam. Kelompok pertama berpendapat bahwa RUU itu penting dan segera disepakati menjadi undang-undang, argument yang diajukan adalah perlunya Negara memberikan perhatian lebih kepada pesantren. Dengan undang-undang maka pesantren mendapat legitimasi kuat untuk mendapatkan hak-haknya dalam proses penyelenggaraan pemerintahan. Kelompok kedua, mereka yang khawatir jika pesantren dan pendidikan keagamaan diatur oleh pemerintaha. Kekhawatiran tersebut bukan tanpa alasan, pemerintah sangat dimungkinkan melakukan intervensi terhadap penyelenggaraan pesantren, mulai dari proses pendirian sampai pada proses layanan pesantren, berupa pendidikan, dakwah penyiaran, pemberdayaan masyarakat, dan pembentukan kebudayaan. Kelompok ketiga, yakni mereka yang setuju dengan catatan tidak memberikan peluang besar kepada pemerintah untuk masuk dalam teknik penyelenggaraan pesantren. Jika keberadaan undang-undang itu berpotensi memberkan ruang terbuka bagi pemerintah untuk melakukan intervensi, maka sudah seyogyanya RUU itu ditolak.

Untuk mengetahui secara lebih mendalam materi muatan RUU Pesantren dan Pendidikan Keagamaan, penulis akan memberikan catatan tertentu terhadap ketentuan dan pasal-pasal yang memunculkan opini beragam di kalangan para kiai. Catatan tersebut adalah sebagai berikut:

$$
30 \mid \text { JURNAL LISAN AL-HAL }
$$


a. Pada konsideran huruf a disebutkan bahwa setiap orang bebas memeluk agama dan beribadat menurut agamanya, memilih pendidikan dan pengajaran dalam satu sistem pendidikan nasional yang meningkatkan keimanan dan ketakwaan serta akhlak mulia dalam rangka mencerdaskan kehidupan bangsa sebagaimana diamanatkan dalam Undang-Undang Dasar Negara Republik Indonesia Tahun 1945.

Penyebutan bahwa memilih pendidikan dan pengajaran dalam satu sistem pendidikan nasional menunjukkan bahwa RUU Pesantren dan Pendidikan Keagamaan tidak bisa dipisahkan dari sistem penyelenggaraan pendidikan nasional. Dalam UU Nomor 20 Tahun 2003 tentang Sistem Pendidikan Nasional (Sisdiknas), pesantren memang menjadi bagian dari Sisdiknas, yaitu diatur dalam ketentuan pendidikan keagamaan. Pertanyaan yang kemudan bermunculan adalah apakah posisi pesantren sama dengan penyelenggaraan pendidikan pada umumnya? Dalam forum silaturahim nasional yang diselenggarakan oleh Pesantren Sukorejo, beberapa kiai kurang sependapat jika pesantren menjadi bagian integral dalam sisdiknas, karena akan berakibat pengaturan yang akan berpotensi menyulitkan penyelenggaraan pesantren, terutama pada aspek penyelenggaraan administrasi. Namun, kiai yang lain justru sependapat dengan sisdiknas, secara ekstrim keberadaan RUU Pesantren dan Pendidikan Keagamaan malah tidak terlalu penting, karena sudah dilindungi oleh UU Sisdiknas.

b. Selain konsideran huruf a, penulis juga mencatat perlunya mencermati konsideran huruf c, beberapa kalimat pernyataan sosiologisnya disebutkan... dalam perkembangannya pesantren dan pendidikan keagamaan masih mengalami ketimpangan pada aspek pembiayaan, dukungan sarana prasarana, sumber daya manusia bermutu, dan kurangnya keberpihakan negara terhadap pesantren dan pendidikan keagamaan agar memiliki kompetensi dan keunggulan yang berdaya saing global. Pernyataan politik yang dituangkan dalam konsideran huruf c sebagai landasan sosiologis pembentukan RUU Pesantren dan Pendidikan Keagamaan memang sangat menarik. Para kiai lebih banyak setuju terhadap usul DPR tersebut. Itu mengindikasikan bahwa peluang mendapatkan hak anggaran dari keuangan yang bersumber dari pendapatan dan belanja Negara akan mengalir ke pesantren-pesantren secara adil dan merata. Di sisi lain, ternyata ada kiai dan pesantren yang jusutru khawatir terhadap perhatian kebijakan politik anggaran. Sudahkan pesantren siap 
dengan segala ketentuan pengelolaan keuangan Negara? Sebagaimana dijelaskan oleh Zamahsyari Dhofier, bahwa penyelengaraan pesantren yang paling pokok adalah pengajaran kitab kuning, sebagai basis pendalaman keilmuan Islam. Kitab-kitab tersebut tidak menjelaskan tentang pengaturan keuangan, hanya memberikan pedoman normative bagaimana pengelolaan keuangan dilakukan dengan cara yang adil dan benar, sesuai ajaran Islam. Kekhawatiran sebagian kiai itu ditolak oleh kiai lainyya. Pesantren sudah siap jika harus mempertanggungjawabkan pengelolaan keuangan Negara. Ilmu praktis tentang keuangan bisa dipelajari, bukankah pemerintah dalam hal memberikan bantuan keuangan selalu disertai pedoman pelaksanaannya.

c. Penjelasan definitif tentang ketentuan pesantren, sebagaimana disebtukan dalam pasal 1 RUU oleh sebagian kiai dan kalangan pesantren justru membingungkan. Ketentuan tersebut terlalu panjang dan tidak simple. Secara ekstrim ada yang mengusulkan supaya definisi pesantren memasukkan pernyataan ajaran Islam Ahlus Sunnah wal Jamaah (Aswaja) sebagai basis kajian dan pendalaman ilmu-ilmu keislaman yang ada di pesantren.

d. Selanjutnya, para kiai juga berpandangan, bahwa pasal 1 angka 7 yang menyebutkan seorang kiai sebagai pendidik harus memiliki kompetensi ilmu agama. Dalam ketentuan UU Sisdiknas dan Peraturan Pemerintah tentang Standar Nasional Pendidikan (SNP), diatur juga standar pendidik. Jika kiai sebagai pendidik harus memiliki kompetensi ilmu agama, pertanyaanya, siapa dan lembaga mana yang akan menguji kompetensi ilmu agama seorang kiai? Dan siapa yang membuat standar kiai sebagai pendidik, apakah sama dengan SNP yang ada.

e. Pasal 3 RUU yang mengatur tentang tujuan penyelenggaraan pesantren dan pendidikan keagamaan menjadi satu kesatuan. Padahal jika diteliti lebih mendalam, penyelenggaraan pesantren dan pendidikan keagamaan berbeda. Pesantren hanya menjadi domain kalangan Islam, sementara pendidikan keagamaan bukan hanya domain dan hak keagamaan tertentu. Maka seharusnya dipisahkan antara pesantren dan pendidikan keagamaan. Ketentuan pasal-pasal yang mengatur pendidikan keagamaan disebutkan dalam pasal 17 sampai pasal 165 yang di dalamnya mengatur pendidikan selain agama Islam. Secara sosiologis dan filosofis tentu berbeda dalam proses penyelenggaraannya. 
Catatan penulis atas "rangkuman" pandangan para kiai terhadap penyelenggaraan pesantren sebagaimana disebutkan dalam RUU tersebut di atas sejalan dengan apa yang menjadi tahapan dalam kebijakan public. William Dunn menyebutkan bahwa dalam tahap kebijakan harus melalui tahap penyusunan agenda dan formulasi serta adopsi. Menurut ketentuan konstitusi dan peraturan pembentukan undang-undang, domain hak konstitusi pembentukan undang-undang dilakukan oleh dua lembaga Negara, yaitu DPR dan Presiden. Dalam tahap adopsi dan formulasi kebijakan, DPR harus berjuang keras untuk menyatukan persepsi terhadap usul RUU. Pengaturan Pesantren tidak hanya menjadi kewenangan Kemenag saja, harus lintas kementerian dan lembaga Negara lainya. Sebelum RUU disetuji bersama DPR dan Presiden, maka tindak lanjut dalam pembahasan tahap kebijakan adalah penerimaan DIM yang sudah disusun oleh Pemerintah.

\section{E. Simpulan}

Keberadaan RUU Pesantren dan Pendidikan Keagamaan yang saat ini dalam proses pembahasan antara DPR dan Pemerintah memiliki nilai strategis bagi penyelenggaraan pesantren. Pijakan dan dasar hukum penyelenggaraan pesantren dalam pengelolaannya akan semakin kuat, karena setiap penyusunan kebijakan politik anggaran yang dituangkan dalam UU tentang APBN setiap tahun harus jelas dasar hukumnya. Ada kekhawatiran jika pesantren diatur melalui Undang-Undang, akan berpotensi otoritas intervensi pemerintah terhadap penyelenggaraan pesantren. Kekhawatiran ini muncul karena akan menjadi peluang distorsi dan desakralisasi pesantren sebagai lembaga tafaqquh fid din. Pesantren akan kehilangan jati diri dan identitas sebagai lembaga yang mandiri. Akankah kurikulum pesantren juga diatur oleh pemerintah.

Sebagian kalangan kiai dan pesantren memberikan catatan dan perhatian kepada DPR dan Presiden agar keberadaan RUU yang akan menjadi Undang-Undang agar memperhatikan kekhasan dan karakteristik pesantren sebagai lembaga layanan masyarakat yang sudah tumbuh berkembang dan mengakar di bumi pertiwi. Undang-undang seharusnya memberikan perlindungan terhadap penyelenggaraan pesantren, bukan sebaliknya memberatkan pesantren. Nilai-nilai patriotisme sudah lama dibangun di pesantren, sudah seharusnya Negara memberikan "balas budi" kepada pesantren dengan tetap menghargai keaneka ragaman pesantren yang ada. Tidak perlu ada uniform pesantren yang diatur dalam undang-undang. Model deskriptif dan normatif Dunn, sebagai model kebijakan yang cukup analitis untuk mengkaji lebih jauh tentang RUU 
Pesantren dan Pendidikan Keagamaan. Selain memang tahap-tahap kebijakan public yang harus diperhatikan dalam proses analisis kebijakan publik.

\section{DAFTAR PUSTAKA}

Agustino, Leo, Dasar-Dasar Kebijakan Publik. Bandung: Alfabeta, 2008. Arifi, Ahmad, Politik Pendidikan Islam: Menelusuri Ideologi dan Aktualisasi Pendidikan Islam di Tengah Arus Globalisasi. Yogyakarta: Teras, 2010.

Bhaghi, Silvano Keo, Negara Bukan-Bukan. Maumere: Ledalero, 2016.

Damsar, Pengantar Sosiologi Politik. Jakarta: Kencana, 2015.

Dhofier, Zamahsyari, Tradisi Pesantren: Studi tentang Pandangan Hidup Kiai. Jakarta: LP3ES, 1982.

Dunn N, William, Analisis Kebijakan Publik. Yogyakarta: Gadjah Mada University Press, 2003.

Fatah, Nanang, Analisis Kebijakan Pendidikan. Bandung: Remaja Rosda Karya, 2012.

Foucault, Michael, Wacana Kuasa/Pengetahuan. Yogyakarta: Bentang Budaya, 2002.

Haryatmoko, Etika Politik dan Kekuasaan. Jakarta: Kompas, 2003.

Profil Pondok Pesantren Mu'adalah. Jakarta: Direktorat Jenderal Kelembagaan Agama Islam/Direktorat Pendidikan Keagamaan dan Pondok Pesantren Departemen Agama, 2004.

Kaelan, Pendidikan Pancasila. Yogyakarta: Paradigma, 2004.

Maliki, Zainuddin, Rekontruksi Teori Sosial Modern. Yogyakarta: UGM Press, 2012.

Mastuhu, Dinamika Sistem Pendidikan Pesantren. Jakarta: INIS, 1994.

Suharto, Edi, Analisis Kebijakan Publik. Bandung: Alfabeta, 2010.

Tilaar, H.A.R. dan Riant Nugroho, KebijakanPendidikan. Yogyakarta: PustakaPelajar, 2009.

Toha, Miftah, Birokrasi Pemerintah dan Kekuasaan di Indonesia. Yogyakarta: Matapenan Institute, 2012.

Umar, Nasaruddin, Rethinking Pesantren. Jakarta: PT. Elex Media Komputindo, Kompas Gramedia, 2014.

Usman, Husaini, Manajemen: Teori, Praktik, dan Riset Pendidikan. Jakarta: Bumi Aksara, 2013.

Varma, S.P, Teori Politik Modern. Jakarta: Rajagrafindo Persada, 2010. Arma, Teori Politik Modern. Jakarta: Rajagrafindo Persada, 2010.

Wahab, Abdul, Solichin, Analisis Kebijaksanaan: Dari Formulasi Ke

34 JURNAL LISAN AL-HAL 
Implementasi Kebijaksanaan Negara, Edisi Kedua. Jakarta: Bumi Aksara, 2001.

Winarno, Budi, Kebijakan Publik: Teori, Proses, dan Studi Kasus. Yogayakarta: CAPS, Center of Academic Publishing Service, 2013.

--------, Kebijakan Publik; Teori, Proses, dan Studi Kasus. Jakarta: CAPS, Center of Academic Publishing Service, 2014.

Draft RUU Pesantren dan Pendidikan Keagamaan, Fraksi PKB dan Fraksi PPP. 
"Perspektif Kiai pada RUU Pesantren \& Pendidikan Keagamaan"

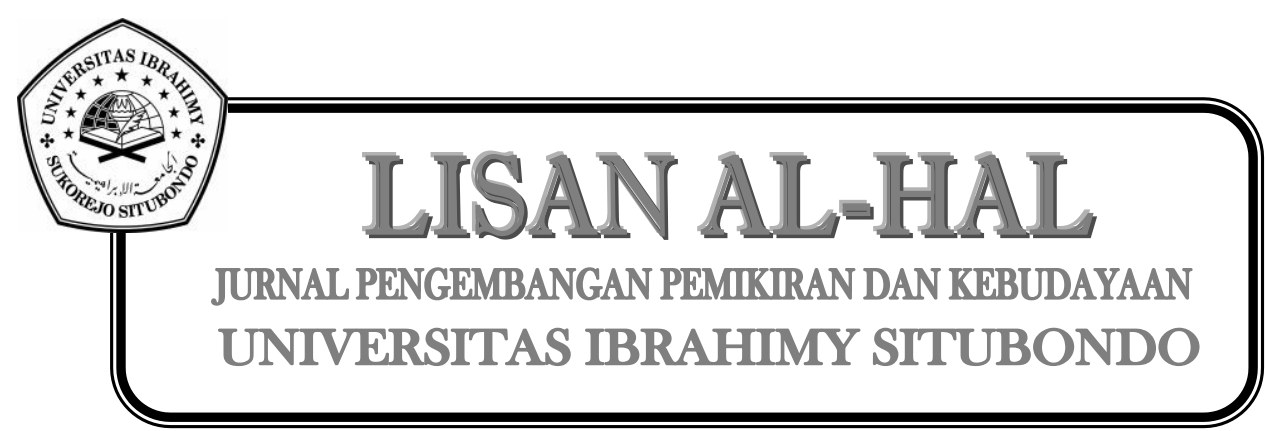

$36 \mid$ JURNAL LISAN AL-HAL 